\title{
Water vapor transport in the Pearl River basin and its influence on NDVI
}

\author{
Yin-Xia WANG, Ji-Sheng ZENG, Ling TANG and Duo ZHUANG \\ South China Sea Institute of Planning and Environmental Research, State Oceanic Administration, Guangzhou, China
}

\begin{abstract}
Using NECP/NCAR monthly average data and 216 months average monthly precipitation data of the University of Delaware during 1982-1999. Analyzed the precipitation vapour transport process affects precipitation in the Pearl River Basin in different seasons. On this basis, the seasonal differences NDVI changes in climate-driven factors in the Pearl River Basin.
\end{abstract}

\section{Introduction}

Pearl River basin is one of the seasonal rains; scientists pay lots of attention on flood season in South China and early summer precipitation. In the 1980s the South China have been systematically studied during the test in South China rainstorms. Water vapor transport process is important in the process of influence of precipitation. Furthermore lots of people made a detailed analysis in the impact of precipitation vapor transport process (Zhou Xiaoxia et 2008). This article focuses on the water vapor transport process influenced precipitation of the Pearl River basin in different season. Climate change is considered to be caused by changes in vegetation cover of one of the main reasons, surface NDVI(Normalized Difference Vegetation Index) certain extent represent the land cover changes, precipitation is one of the important climate factors, this paper analyzes the changes in precipitation driving influence of NDVI in the Pearl River basin.

\section{Data and Methods}

Using NECP / NCAR monthly mean data in 1982-1999, including eight standard pressure values from $300 \mathrm{~Pa}$ to $1000 \mathrm{~Pa}$ layer wind data (u, v components), specific humidity $\mathrm{q}$ and the corresponding surface pressure data ps data with horizontal grid of $2.5^{\circ} \times 2.5^{\circ}$. Precipitation data used in this paper is the University of Delaware 1982--1999 total of 216 monthly average rainfall gridded data[1], with a resolution of $0.5^{\circ} \times 0.5^{\circ}$. NDVI data is provided by GIMMS during 1982-1999, with a resolution of $0.25^{\circ} \times 0.25^{\circ}$.

In this paper, the water vapor transmission intensity is defined as the vertical integral water vapor flux from the ground to $300 \mathrm{pa}$. Monthly average data is used to calculate the water vapor transport of constant weight. According to tian-jun zhou (1999), such as constant component is one order of magnitude larger than the transient components, is to determine the main part of the water vapor transport, especially in the land, so the calculation is reasonable.

The water vapor flux calculation formula is:

Zonal water vapor flux:

$$
Q_{\lambda}=\frac{1}{g} \int_{300}^{p_{s}}(u q) d p
$$

Vertical water vapor flux:

$$
Q_{\varphi}=\frac{1}{g} \int_{300}^{p_{s}}(v \boldsymbol{q}) d p
$$

\section{The Moisture Balance And Precipitation In The Pearl River Basin}

It is a multi-year average moisture balance of payments and the Pearl River Basin precipitation inFigure 1. As it can be seen from the figure moisture change and precipitation changes are substantially synchronized. beginning from January vapor and precipitation are fast rising after April, the Pearl River Basin in the South China flood season, also in April after an increase of precipitation rapid acceleration, moisture balance to maintain a strong rise in the state, to June reached the maximum water vapor and precipitation simultaneously, from June to August, began a slow decline, water vapor and precipitation after a sharp decline in September, especially in November and eleven February moisture balance is negative, namely the Pearl River Basin as a source of water vapor and outward transport of water vapor, so especially in the winter and less precipitation. Pearl River Valley in the monsoon zone, therefore its monsoon rainfall and the water vapor has a significant impact on the transformation and strong monsoon cause 
a corresponding change in the transport of water vapor, which in turn cause changes in water vapor transport in the Pearl River Basin, which have an impact on precipitation.

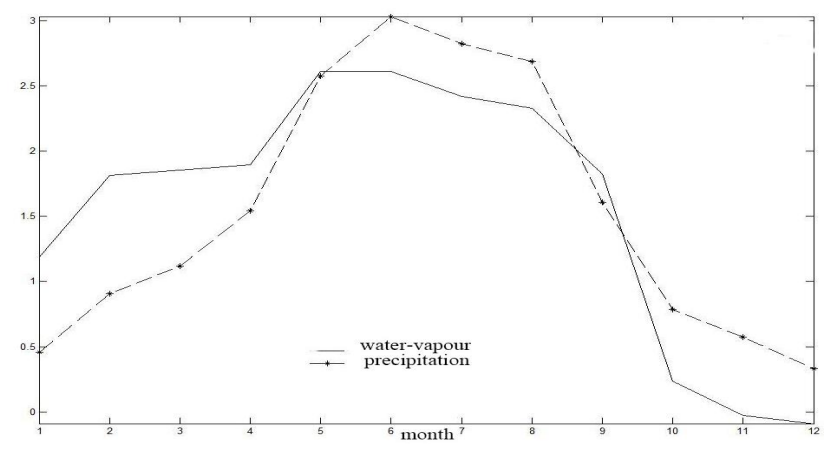

Figure 1. Annual Average Seasonal Changes in Precipitation And Water Vapor Transport (Standardized Data)

\section{Water Vapor Transport Process In Each Season}

Figure 2 is multi-year average of whole layer moisture flux for each season during 1982 to 1999 . In winter you can see the water vapor in mainland China mainly through input westerly water vapor across the Bay of Bengal, Myanmar and Thailand entered into the Chinese mainland South, and the South China Sea due to the winter wind control, water vapor cannot enter from the South China Sea to the Chinese mainland, while the West Pacific Chinese mainland as a vapor outflow area. In the spring westerly belt is still an important input in mainland China with moisture, since the beginning of the monsoon establishment of water vapor transport in the Bay of Bengal to the southeast into the east dominated by the winter to transport, the South China Sea has become an important source of water vapor in the south, the channel is still the Pacific outlet channel. In summer, the monsoon has grown strong and prosperous, in the Bay of Bengal was strong meridional transport, between $18^{\circ} \mathrm{N}$ to $30^{\circ} \mathrm{N}$ in the Bay of Bengal westerly interruption, but remained at high latitudes transport moisture to the Chinese mainland, the South China Sea was southwest monsoon controlled by one of the main sources of water vapor southeastern China. In the fall, the low-latitude westerlies still break out in the Bay of Bengal, entered the Bay of Bengal to the mainland vapor began to show obvious bias of the East, the South China Sea began to control the northeast monsoon, the Chinese mainland has become a regional output moisture. You can see into the Chinese water vapor mainly from the South China Sea, the Bay of Bengal, westerly and Pacific region China mainland vapor output, this paper selected four channels, analyze it and the Pearl River Basin Precipitation: South China Sea channel: $\left(20^{\circ} \mathrm{N}, 110^{\circ} \mathrm{E}-117.5^{\circ} \mathrm{E}\right)$; Bay of Bengal passage: $\left(20^{\circ} \mathrm{N}, 85^{\circ} \mathrm{E}-100^{\circ} \mathrm{E}\right)$; Pacific channel: $\left(25^{\circ}\right.$ $\left.\mathrm{N}-30^{\circ} \mathrm{N}, 120^{\circ} \mathrm{E}\right)$; westerly passage: $\left(20^{\circ} \mathrm{N}-27.5^{\circ} \mathrm{N}\right.$, $\left.82.5^{\circ} \mathrm{E}\right)$.

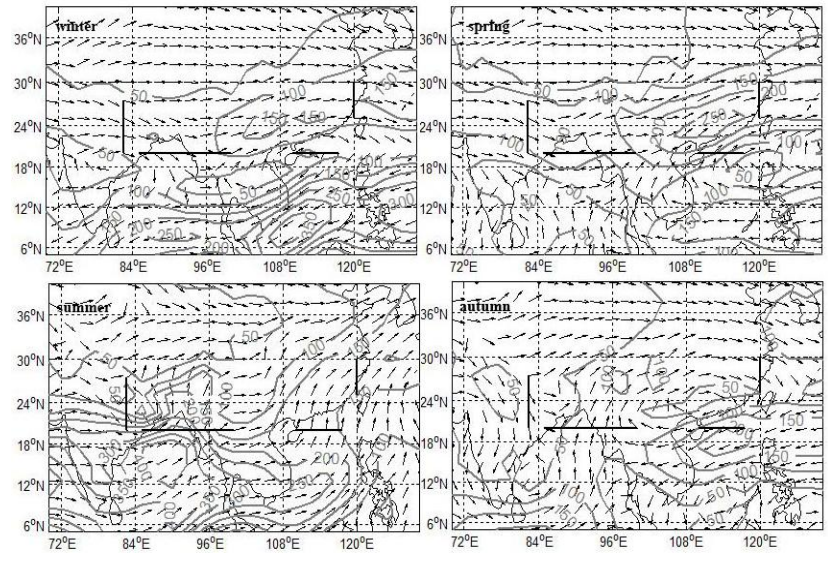

Figure 2. Annual Average Water Vapor Transport ( the Arrows Indicate The Direction of The Contour of the Water Vapor Transport Size.)

Table 1 shows the mean and standard deviation, and correlation coefficient of water vapor channel in four seasons with the Pearl River Basin precipitation. Table 1a indicates in descending order of intensity of winter moisture passage to the Pacific, westerlies, the South China Sea and the Bay of Bengal. Pearl River Basin is closely related to the degree of precipitation followed by the South China Sea, the Bay of Bengal, the Pacific and the westerlies, the South China Sea where the channel significantly by $99 \%$ confidence. Table $1 \mathrm{~b}$ can be seen, in descending order of spring water vapor channel strength for the Pacific channel, the westerlies, the South China Sea and the Bay of Bengal, and spring precipitation and the closeness of the Pearl River Basin were westerly, Bay of Bengal, the South China Sea and the Pacific Ocean. And westerly passage significantly by $95 \%$ confidence, the Bay of Bengal by a significant $90 \%$ confidence. Table $1 \mathrm{c}$ is the information of each channel in summer, you can see the strength of each channel in descending order of the Bay of Bengal, the South China Sea, the Pacific and the westerlies, and the Pearl River Basin and the closeness of summer rainfall in the order of the South China Sea, the Bay of Bengal, the Pacific and the westerlies, and significant South China Sea passage through the $99 \%$ confidence, however, and significant obvious other channels, it may be the South China Sea summer southwest monsoon is controlled, its water vapor transport is the main source of the Pearl River Basin water vapor, while the other channel very small compared to the impact. In the autumn (Table 1d) vapor passage strength decreasing order, the South China Sea, the Bay of Bengal, the Pacific and the westerlies, and each passage of water vapor and the closeness of the Pearl River Basin autumn rainfall in the order of the South China Sea, the Pacific Ocean, the Bay of Bengal and the westerlies, westerlies and relationship between the Bay of Bengal and autumn precipitation Pearl River Basin is not obvious, the South China Sea and the relevant channel significantly by $99 \%$ confidence, significant correlation between the Pacific Ocean through the passage $90 \%$ confidence. 
Table 1a. The Mean and Standard Deviation of Water Vapor Channel, And Correlation Coefficient Between It and Precipitation (Winter)

\begin{tabular}{llll}
\hline $\begin{array}{l}\text { Water vapor } \\
\text { channel }\end{array}$ & mean & $\begin{array}{l}\text { Standard } \\
\text { deviation }\end{array}$ & $\begin{array}{l}\text { correlation } \\
\text { coefficient }\end{array}$ \\
\hline $\begin{array}{l}\text { South China } \\
\text { Sea Channel }\end{array}$ & -60.6 & 22.8 & $0.65^{*}$ \\
$\begin{array}{l}\text { Channel Bay of } \\
\text { Bengal }\end{array}$ & -9.7 & 8.6 & -0.32 \\
$\begin{array}{l}\text { Pacific channel } \\
\text { Westerly }\end{array}$ & 110.0 & 22.8 & 0.31 \\
passage & 87.7 & 32.7 & 0.27 \\
\hline
\end{tabular}

Table 1b. The Mean And Standard Deviation Of Water Vapor Channel, And Correlation Coefficient Between It And Precipitation (Spring)

\begin{tabular}{llll}
\hline $\begin{array}{l}\text { Water vapor } \\
\text { channel }\end{array}$ & mean & $\begin{array}{l}\text { Standard } \\
\text { deviation }\end{array}$ & $\begin{array}{l}\text { correlation } \\
\text { coefficient }\end{array}$ \\
\hline $\begin{array}{l}\text { South China } \\
\begin{array}{l}\text { Sea Channel } \\
\text { Channel Bay of }\end{array}\end{array}$ & 81.4 & 26.3 & 0.35 \\
$\begin{array}{l}\text { Bengal } \\
\text { Pacific channel }\end{array}$ & 21.5 & 12.7 & $-0.38^{\square}$ \\
& & 29.9 & -0.32 \\
$\begin{array}{l}\text { Westerly } \\
\text { passage }\end{array}$ & 169.9 & 23.8 & $0.47^{\Delta}$ \\
& & & \\
\hline
\end{tabular}

Table 1c. The Mean and Standard Deviation of Water Vapor Channel, and Correlation Coefficient Between It and Precipitation (Summer)

\begin{tabular}{lcll}
\hline $\begin{array}{l}\text { Water vapor } \\
\text { channel }\end{array}$ & mean & $\begin{array}{l}\text { Standard } \\
\text { deviation }\end{array}$ & $\begin{array}{l}\text { correlation } \\
\text { coefficient }\end{array}$ \\
\hline $\begin{array}{l}\text { South China } \\
\text { Sea Channel }\end{array}$ & 157.4 & 36.9 & $0.64^{*}$ \\
$\begin{array}{l}\text { Channel Bay of } \\
\text { Bengal }\end{array}$ & 157.6 & 15.6 & 0.14 \\
$\begin{array}{l}\text { Pacific channel } \\
\begin{array}{l}\text { Westerly } \\
\text { passage }\end{array}\end{array}$ & 123.5 & 63.3 & -0.1 \\
\hline
\end{tabular}

Table 1d. The mean and Standard Deviation of Water Vapor Channel, and Correlation Coefficient between It and Precipitation (autumn)

\begin{tabular}{llll}
\hline $\begin{array}{l}\text { Water vapor } \\
\text { channel }\end{array}$ & mean & $\begin{array}{l}\text { Standard } \\
\text { deviation }\end{array}$ & $\begin{array}{l}\text { correlation } \\
\text { coefficient }\end{array}$ \\
\hline $\begin{array}{l}\text { South China } \\
\begin{array}{l}\text { Sea Channel } \\
\text { Channel Bay of }\end{array}\end{array}$ & -63.6 & 26.1 & $0.58^{*}$ \\
$\begin{array}{l}\text { Bengal } \\
\text { Pacific channel }\end{array}$ & 38.7 & 15.4 & 0.015 \\
$\begin{array}{l}\text { Westerly } \\
\text { passage }\end{array}$ & 29.9 & 29.4 & $0.40^{\square}$ \\
\hline
\end{tabular}

Note: * indicates significant by $99 \%$ confidence; $\Delta$ indicates

significant by $95 \%$ confidence; $\square$ indicates significant by $90 \%$ confidence.

\section{Seasonal and Interannual Svd Analysis Between Precipitation And Ndvi In Pearl River Basin}

First, the Pearl River Basin precipitation and NDVI years SVD(Singular Value Decomposition) were analyzed and discussed in both years coupled modes. Figure 3 shows the first mode and the spatial distribution of both the time coefficients, and the first mode and explained reached $97.17 \%$, i.e., the first mode explains the relationship between the main coupling. First look abnormal distribution of precipitation, with significant precipitation change in the consistency of the direction of the entire Pearl River Basin, but things change in strength but has differences, changes in precipitation in the eastern part of the year is less than the west, and generally to $110^{\circ} \mathrm{E}$ is bounded to the west differences oriented east-west and north-south difference is based on the east side of the main. NDVI and rainfall during the year abnormal distribution similarities in NDVI change the direction of the entire Pearl River Basin is also consistent, the same as the east and west high. This configuration instructions when abnormal changes in precipitation, NDVI also have a similar change. From both the time coefficient can see NDVI significantly lag behind changes in precipitation from January to April rainfall anomalies and negative precipitation gradually increased, but the NDVI and lag 2-3 months began to increase in precipitation June reached the maximum, but you want to reach the maximum NDVI in August. From the spatial distribution and temporal change, the increase or decrease of changes in precipitation on NDVI has a hysteresis effect is the same but the direction of change.
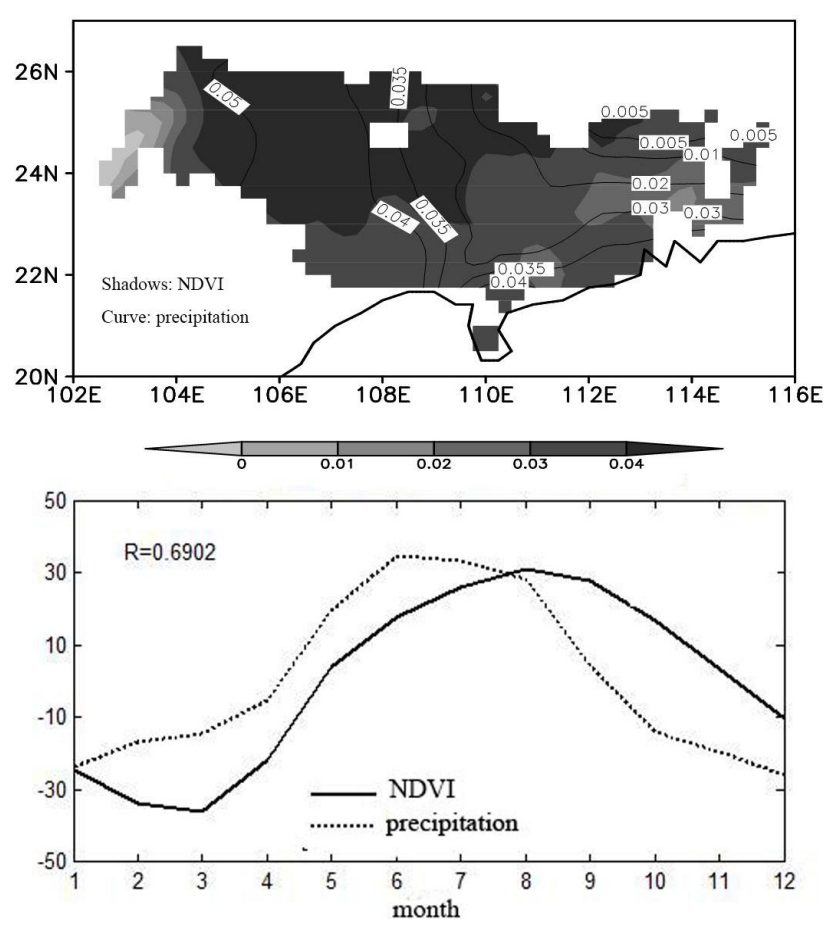

Figure 3. NDVI and Precipitation Season Svd First Mode Field Space and Time Field 
Figure 4 is a scale SVD annual precipitation and NDVI seasonal analysis. The first mode of explained variance rate of four seasons from winter to autumn as follows: $86.38 \%, 58.39 \%, 78.29 \%$ and $58.58 \%$, showing the first mode of the two variance possession major contribution.

In winter, the spatial distribution of precipitation anomalies and the same number from west to east, but NDVI in the distribution space is not the same number in the western presence of two positive centers, others are negative. Overall, the distribution of precipitation anomalies and distribution of NDVI anomalies of opposite sign in the space. See the first two modes winter time coefficient, correlation coefficient of 0.5 , more than $95 \%$ confidence level. And both the time coefficient is substantially the same number, indicating that in addition to the east of $110^{\circ} \mathrm{E}$ in both the positive change in the intensity distribution at two centers in other regions NDVI change direction and precipitation are consistent, and basically consistent.

In spring, abnormal distribution of precipitation still has the same number of spaces, and in the center of the Pearl River Basin strongest change, decreasing to four weeks. But NDVI spatial anomalies apparent something different, east due west negative. Both the first mode of the time factor, the correlation coefficient reaches 0.73 , more than $99.9 \%$ confidence level, and substantially the same sign. Description in the east, the Pearl River Basin precipitation and NDVI reverse change, while in the West, compared to the same changes.

In summer, the spatial distribution of precipitation anomalies in the basin are still the same number, NDVI and precipitation versa but different numbers. Instead of both the strength and the distribution center. Correlation coefficients between 0.57 time, more than 95\% confidence level, and substantially the same sign. This configuration instructions space and time, in the opposite direction of change in summer precipitation and NDVI.

In autumn, precipitation anomaly field is still the same number throughout the region, the central small and large sides. NDVI throughout the region is substantially the same number, but the number and distribution of inverse precipitation anomalies, strong northwest southeast weaker. Both time correlation coefficient reached 0.49 , more than $95 \%$ confidence level, and still is with the main positive and negative. Such configuration instructions in the autumn precipitation and NDVI change is in the opposite direction.

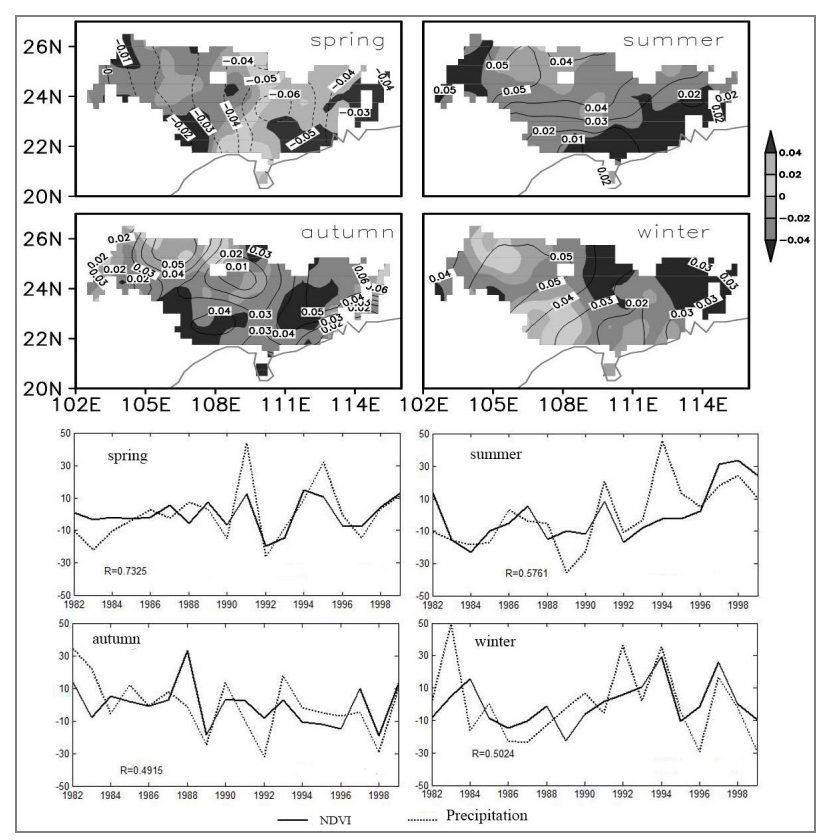

Figure 4. NDVI and Precipitation in Four Seasons on the Occasion of the First Svd Mode (Shadows: Ndvi, Curve: Precipitation)

\section{Conclusion}

Through the above analysis we can get the following conclusions:

(1) Pearl River Basin precipitation and the water vapor has a significant change in sync, it began to rise in January, reaching the maximum in June, after the rapid decline starting in August.

(2) the impact of the main sources of water vapor in the Pearl River Basin of South China Sea, the Bay of Bengal, the westerlies, the Pacific region is predominantly a Chinese output moisture. Vary in different seasons affect the Pearl River Basin precipitation mainly water vapor channel differences, major winter the South China Sea channel followed by the Bay of Bengal; the close relationship between the spring followed by westerlies, the Bay of Bengal, South China Sea and the Pacific channel; in the summer the South China Sea passage and the Pearl River Basin Precipitation most closely, the other channel is not obvious; the South China Sea and the main autumn passage and their closely related to the Bay of Bengal.

(3) years of precipitation and NDVI SVD analysis showed increased or decreased precipitation changes in NDVI has a lag effect, but the direction of change is the same; in different seasons of the SVD precipitation and NDVI analysis shows that in the winter in most parts of the Pearl River Basin NDVI change direction and the direction of change precipitation consistency and east of $110^{\circ} \mathrm{E}$ between changes in the intensity distribution are basically the same; east, rainfall and NDVI reverse changes in the Pearl River Basin in the spring, and in the west compared to the same change; in precipitation and NDVI opposite direction of change; changes in 
precipitation and NDVI autumn is in the opposite direction.

\section{References}

[1]http://apdrc.soest.hawaii.edu:80/dods/public_data/Inte rpolated_precipitation/UDel_prec_airT.

[2] Jis-han Xue. Rainstorm research in South China In the summer of 1994[M]. Beijing, China Meteorological Press, 1999: 185.

[3] Xiao-xia Zhou, Yi-hui Ding, Pan-xing WANG. Water vapor transport summer Asian monsoon region and its impact on precipitation in China [J]. Meteorological Science. 2008.9,28: 193-203.

[4] Yun-hao Chen, Xiao-bing Li, Pei-jun Shi .1983 Chinese land NDVI changing climatic factor driving the 1992 analysis [J] Chinese Journal of Plant Ecology, 2001,25 (6): 716-720.

[5] Ben-gang LI, Song Tao, R.W.Dawson. Relations between AVHRR NDVI and ecoclimatic parameters in China[J]. Remote Sensing,2002,23(5):989-999.

[6] Willmott C.J, Robeson S.M. Climatologically aided interpolation (CAI) of terrestrial air temperature $[\mathrm{J}]$. International Journal of Climatology, 1995, 15(2):221-229.

[7] Krishnamurti T N.Numerical Simulation of Somali Jet[J].Journal of Atmaspheric Sciences, 1976,33:2350-2362.

[8] Shi-yan Tao, Yi-hui Ding. Observational Evidence of the Influence of the Qinghai-Xizang (Tibet) Plateau on the Occurrence of Heavy Rain and Severe Convective Storms in China[J].Bulletin of the American Meteorological Society,1981,62(1):23-30.

[9] Tian-jun Zhou,Xue-hong Zhang, Shao-wu Wang. Marine component of global water cycle research [J]. Journal of meteorological, 1999, 57 (3) : 264-282. 